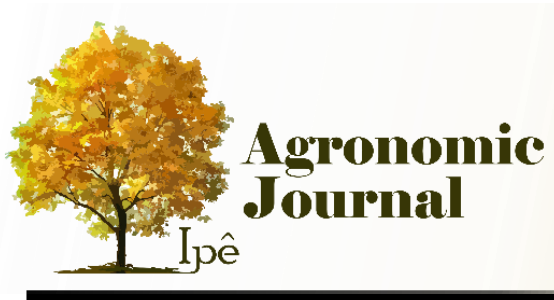

\title{
INFLUENCE OF INSECTICIDES AND FUNGICIDES IN THE RIZOSPHERE OF UNCONVENTIONAL FOOD PLANTS (UFP's)
}

\author{
INFLUÊNCIA DE INSECTICIDAS E FUNGICIDAS NA RIZOSFERA DE PLANTAS ALIMENTÍCIAS NÃO \\ CONVENCIONAIS (PANC'S)
}

Jean César de Oliveira ${ }^{1}$, Aline Barbosa Arruda ${ }^{1}$, Ana Paula Cipriano Borges ${ }^{1}$, Matheus Vinicius Abadia Ventura $^{2}$, Renato Cardoso Teixeira ${ }^{2}$, Ricardo Araújo Alves ${ }^{2}$

1 Faculdade Evangelica de Goianésia, Goianesia, Goias, Brazil.

2 Instituto Federal Goiano - Rio Verde, Rio Verde, Goias, Brazil.

\begin{tabular}{l} 
Info \\
\hline Recebido: 09/2019 \\
Publicado: $11 / 2019$ \\
ISSN: 2595-6906 \\
Palavras-Chave: Vegetação. Micro- \\
organismos, rizosfera, xenobióticos, \\
exóticos.
\end{tabular}

.Keywords: greenery, microorganisms, rhizosphere, xenobiotics, exotic.

\begin{abstract}
The rhizosphere is the region of influence of the roots of the plants in the soil that provide environment favorable to the maximum microbial activity. As the maximum microbial activity occurs in the rhizosphere, several benefits are added to this environment, since it becomes a source of biodiversity of microorganisms capable of maintaining the ecological balance, and also provide significant improvements for plants the soil and for the environment. The objective of this work was to evaluate the influence of xenobiotics (fungicides and insecticides) in an isolated and combined way on the microbial diversity benefices of the
\end{abstract}

rhizosphere under the cultivation of 4 unconventional food plants (UFP's) or exotic vegetables. This work was performed with a randomized complete block design in the $4 \times 4$ factorial scheme, the first factor being the cultures: Fragaria vesca L. ("morango"), Rumex acetosa L. ("azedinha"), Tropaeolum majus L. (capuchin - "capuchinha") and Stachys Lanata L. ("peixinho") and the second factor (application with insecticide, application with fungicide, insecticide / fungicide application and control) with 4 replicates. There was no statistical difference between the cultures in relation to the numbers of fungal and soil CFUs and that the application of xenobiotics (fungicides and insecticides, isolated and combined) did not affect the microbial diversity in the soil cultivated with the crops. The xenobiotics did not affect the microbial diversity present in the soils of the tested cultures, being similar statistically with the control. UFP's crops did not present statistical differences regarding CFU in cultivated soils.

\section{Resumo}

A rizosfera é a região de influência das raízes das plantas no solo que proporcionam ambiente favorável à elevada atividade microbiana. Como a elevada atividade microbiana ocorre na rizosfera, diversos benefícios são adicionados a esse ambiente, pois se torna uma fonte de biodiversidade de microrganismos capazes de manter o equilíbrio ecológico, além de proporcionar melhorias significativas para as plantas do solo e para o meio ambiente. O objetivo deste trabalho foi avaliar a influência de xenobióticos (fungicidas e inseticidas) de forma isolada e combinada nos benefícios da diversidade microbiana da rizosfera sob o cultivo de 4 plantas alimentares não convencionais (UFPs) ou vegetais exóticos. Este trabalho foi realizado com delineamento de blocos completos casualizados no esquema fatorial 4 x 4, sendo o primeiro fator as culturas: Fragaria vesca L. ("morango"), Rumex acetosa L. ("azedinha"), Tropaeolum majus L. ( capuchinha - "capuchinha") e Stachys Lanata L. ("peixinho") e o segundo fator (aplicação com inseticida, aplicação com fungicida, aplicação e controle de inseticida / fungicida) com 4 repetições. Não houve diferença estatística entre as culturas em relação ao número de UFC de fungos e solo e que a aplicação de xenobióticos (fungicidas e inseticidas, isolados e combinados) não afetou a diversidade microbiana no solo cultivado com as culturas. Os xenobióticos não afetaram a diversidade microbiana presente nos solos das culturas testadas, sendo similar estatisticamente ao controle. As culturas da UFP não apresentaram diferenças estatísticas em relação à UFC em solos cultivados. 


\section{INTRODUCTION}

The rhizosphere is the region of influence of the roots of the plants in the soil that provide environment favorable to the maximum microbial activity. This environment is established by the very interaction between the soil and the roots of the plants that are attractive to microbial activity and is therefore extremely important both for soil quality and for the good development of plants (Embrapa Meio Ambiente, 2018).

As the maximum microbial activity occurs in the rhizosphere, several benefits are added to this environment, since it becomes a source of biodiversity of microorganisms capable of maintaining the ecological balance, and also provide significant improvements for plants the soil and for the environment. In the rhizosphere are innumerable bacteria capable of producing secondary metabolites, such as auxin, antibiotics, acids, among others. Some act potently in the control of fungi and pathogens that affect the root system, others act in the biodegradation of xenobiotic molecules or even in the degradation of complex natural compounds (Embrapa Meio Ambiente, 2018).

In this way it is possible to verify the immense contribution of the rhizosphere to the plants and to the environment, since the soil microbiota favors the development of the plants through symbiotic associations, control of root pathogens, release of stimulating metabolites, among numerous other contributions. For the environment is extremely important in the bioremediation of contaminants, especially xenobiotics that can cause soil damage to surface and groundwater. Even with so many benefits added to the rhizospheric microbiota, some actions have been causing the population imbalance of this environment. This is mainly due to the use of xenobiotic compounds capable of reducing microbiological activity drastically.
According Figueiró (2012), the use of xenobiotic substances in the soil can cause significant changes in the abiotic component of the system, as well as reactions in the biotic community of the same. There is clear evidence that many xenobiotics target nontarget organisms from the soil, with varying impacts, which may be stimulatory or inhibitory.

Many xenobiotics have harmful effects on the rhizotropic organisms, which may lead to the selective elimination of certain individuals, causing further transformation in the ecological and functional structure of the biological community (Gaylarde et. al., 2005). When using xenobiotics, there is a strong tendency to select organisms that are able to survive in these new conditions, as well as eliminate other types of fragile microorganisms that may even lead to the extinction of certain organisms.

Several factors may interfere in the interaction of the xenobiotic with the medium in which it was inserted, as the amount of application, the soil environment, the availability of food resources at the time of application, and the greater the concentration and persistence of the product, the greater the damage. In some crop groups, the application of pesticides may be essential, because some cultivars are susceptible to pest and disease attack, or because they have few control methods.

Therefore, according to Nakano (1999), vegetables are examples of demanding crops in pesticides applications, which happens because there are a lot of pests and diseases that affect these cultivars, and also because in most cases there are few control alternatives besides chemical control.

The rhizosphere of exotic vegetables, also known as unconventional food plants (UFP's), Fragaria vesca L. (strawberry - "morango"), Rumex acetosa L. (“azedinha"), Tropaeolum majus L. (capuchin "capuchinha") and Stachys lanata L. (fish - "peixinho") after application of the insecticide (Abamectim nortox) 
and fungicide (AMISTAR) observing their interference on the soil microbiota.

The strawberry (Fragaria vesca L.) of the family Rosaceae, is an herbaceous plant of low growth, perennial culture with better development in regions of mild climate and cold, however they can be cultivated in regions of warm climate (Antunes \& Raseira, 2006). This crop is affected directly and indirectly by the attack of fungi, bacteria, viruses and nematodes, being the main diseases caused by fungi as Colletotrichum fragariae and Colletotrichum acutatum (anthracnose) which causes respectively rhizome and black-flower rot, bacterial diseases such as the angular spot originated by Xanthomonas fragariae, nematoid diseases such as the nematode Meloidogyne ssp., as well as numerous other viral diseases (Simon et al., 2005).

The Rumex acetosa L. ("azedinha") is a herbaceous plant of the family Polygonaceae, used in human food in the in natura form, soups and salads (Leone, 2009; Mapa, 2010). Perennial culture, reaching about $20 \mathrm{~cm}$ of height and cultivated in mild climate, better indicated for the states of Rio Grande do Sul and Minas Gerais (Silva et al., 2013), not tolerating temperatures below $5^{\circ} \mathrm{C}$ and above $30^{\circ} \mathrm{C}$, requires well drained, uncompressed soils with lots of organic matter.

The preparation of flower beds should be carried out as for any other vegetable, and can be grown all year round in mild climate, it is recommended to cultivate from March to July. Planting through propagules of the twigs in definitive spacing of 20 to 25 $\mathrm{cm}$ between plants. As a rustic vegetable does not require much cultural activities, as the most common pests highlight beetles and kitties, diseases are nematodes of the genus Meloidgyne, which reduces the growth of the plant.

According to the Secretaria de Atenção à Saúde (2015), the plant Tropaeolum majus L. is known among several popular names among them: "capuchinha" capuchin, chaguinha, chagas, parrots, flower-of-blood,
Mexican watercress, nasturtium flower, spur-of-cock, Peruvian watercress. It is a vegetable that has all the edible parts, annual cultivar, with easy propagation, has characteristic to attract lepidoptera, and to remove aphids and beetles.

According Duarte (2018), the capuchin is a hardy vegetable with easy adaptation in diverse climatic conditions, arriving to bloom almost every year, develop in any type of soil, but with superior development in light and little sandy soils, well drained soils and rich in organic matter can be planted, throughout the year, having a better development in times of higher temperatures, being its multiplication by seeds and staquias.

According Embrapa Hortaliças (2018), Stachys lanata (fish - "peixinho"), belonging to the family Lamiaceae, herbaceous, perennial, wild of regions of mild climate of Europe and Asia, in Brazil cultivated in the South, Southeast and Center West regions, reaching $20 \mathrm{~cm}$ of height with growth in the form of clumps, not blooming in Brazilian conditions. This cultivar requires well-drained soils with a good content of organic matter, being able to be cultivated the whole year as long as there are conditions favorable for the development being its propagation by means of dismembered clumps. The cultural dealings are not very demanding because of their rusticity, performing according to the need of the plant.

The objective of this work was to evaluate the influence of xenobiotics (fungicides and insecticides) in an isolated and combined way on the beneficial microbial diversity of the rhizosphere under the cultivation of four unconventional food plants (UFP's) or exotic vegetables.

\section{MATERIALS AND METHODS}

The work was carried out at the School of Agronomy of the Faculdade Evangelica de Goianésia (FACEG), in the city of Goianésia - GO. The design 
was randomized in randomized blocks with the $4 \times 4$ factorial scheme with 4 replications, with daily follow up. In this work it was necessary to use the greenhouse and the laboratory of the institution.

In the greenhouse with a 50\% sombrite structure, 64 pots were planted with 64 seedlings of exotic vegetables, of which 16 were seedlings of Fragaria vesca L. (strawberry - "morango"), Rumex acetosa L. ("azedinha"), Tropaeolum majus L. (capuchin "capuchinha") and Stachys lanata (fish - "peixinho"), which consisted of the 1 st factor. The second factor was the use of xenobiotics: application of insecticide, fungicide and insecticide / fungicide, in addition to control (control) treatment.

The planting, replanting and acclimatization of the seedlings occurred during 68 days, after that period the applications of xenobiotics were started, with two applications of insecticide with a 30 day interval between the applications, using $0.5 \mathrm{ml}$ for each 5 liters of water. With the fungicide were carried out six applications with the interval of 7 days each, using 0.5 $\mathrm{ml}$ for each 5 liters of water, totaling 120 days of experimentation.

The analyzed soil was collected after the last application (15 days of the insecticide and 7 days of the fungicide), two samples of each treatment were used in the xenobiotic influences analyzes: Abamectim Nortox (acaricide and biological insecticide, contact action and ingestion, with chemical group of avermectins) and AMISTAR TOP (systemic fungicide with chemical group of azoxystrobin, strobilurin, difenoconazole, triazole), on the rhizosphere of each culture.

In the laboratory, the quantitative analyzes of the rhizosphere microorganisms were carried out, comparing the results obtained in the experiments with the use of xenobiotics, in order to infer their interference on the rhizosphere of such vegetables. At the end of the experiment the data obtained between the treatments were compared with data available in the literature to support the discussions and conclusion of the work.

The obtained data were submitted to analysis of variance and comparison of means in statistical software by the Scott Knott test at the 5\% probability level.

\section{RESULTS AND DISCUSSIONS}

The statistical data on the average colony forming units (CFU) in the soil collected from the four crops are described in Table 1. It is possible to observe that there was no statistical difference between the cultures in relation to the numbers of CFUs of fungi and soil bacteria.

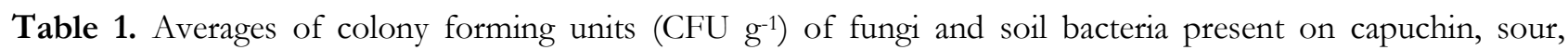
strawberry and goldfish crops.

\begin{tabular}{|c|c|c|c|c|}
\hline \multirow{3}{*}{$\begin{array}{c}\text { Treatments } \\
\text { Capuchin - "Capuchinha" }\end{array}$} & \multicolumn{4}{|c|}{ Averages } \\
\hline & \multicolumn{2}{|c|}{ Fungi (CFU g-1) } & \multicolumn{2}{|c|}{ Bacteria (CFU g-1) } \\
\hline & 0.578125 & $\mathrm{a}$ & 10.578125 & a \\
\hline "Azedinha" & 1.093750 & $\mathrm{a}$ & 12.718750 & $\mathrm{a}$ \\
\hline Strawberry - “Morango" & 1.109375 & $\mathrm{a}$ & 12.718750 & a \\
\hline Fish - "Peixinho" & 1.187500 & $\mathrm{a}$ & 13.500000 & $\mathrm{a}$ \\
\hline CV (\%) & \multicolumn{2}{|c|}{84.24} & \multicolumn{2}{|c|}{39.88} \\
\hline
\end{tabular}

\footnotetext{
* equal letters are considered statistically similar and the different letters are considered statistically different.
} 
It is possible to observe in Table 2 that there was no statistical difference between the xenobiotics among themselves and in relation to the control treatment regarding the numbers of CFUs of fungi and bacteria. In this way. it was possible to observe that the application of xenobiotics (fungicides and insecticides, isolated and combined) did not affect the microbial diversity in the soil cultivated with the crops.

Table 2. Means of colony forming units $\left(\mathrm{CFU} \mathrm{g} \mathrm{g}^{-1}\right)$ of fungi and soil bacteria present for the treatments with xenobiotics: insecticide, fungicide and insecticide/fungicide, besides the control treatment.

\begin{tabular}{|c|c|c|c|c|}
\hline \multirow{3}{*}{$\begin{array}{l}\text { Treatments } \\
\text { Insecticide }\end{array}$} & \multicolumn{4}{|c|}{ Averages } \\
\hline & \multicolumn{2}{|c|}{ Fungi (CFU g-1) } & \multicolumn{2}{|c|}{ Bacteria (CFU g-1) } \\
\hline & 0.812500 & $\mathrm{a}$ & 9.781250 & $\mathrm{a}$ \\
\hline Fungicide & 0.812500 & $\mathrm{a}$ & 12.312500 & $\mathrm{a}$ \\
\hline $\begin{array}{l}\text { Insecticide/ } \\
\text { Fungicide }\end{array}$ & 1.140625 & $\mathrm{a}$ & 12.859375 & $\mathrm{a}$ \\
\hline Witness & 1.203125 & $\mathrm{a}$ & 14.562500 & $\mathrm{a}$ \\
\hline CV (\%) & & & & \\
\hline
\end{tabular}

* equal letters are considered statistically similar and the different letters are considered statistically different.

In the work of Reis et al. (2010), the endosymbiotic microorganisms were not significantly affected as a result of the application of the herbicide gyphosate and the combination of insecticide + fungicide (fomesafen + fluazifop-p-butyl) in the soybean crop. The insecticides carbofuran, endosulfan, thiamethoxam, fipronil and imidacloprid did not cause any effect on Gluconacetobacter diazotrophicus in Fernandes et al. (2013) and diabetic bacteria Herbaspirillum seropedicae in the work of Procópio et al. (2010), both in sugarcane culture.

In the work of Pereira et al. (2010), with the treatment of the soybean seeds with carbendazim + thiram and thiabendazole + thiram reduced the nodulation, demonstrating a negative effect on the microorganisms. In the work of Marks et al. (2013), in the soybean crop, the fungicides Protreat and Maxim $\mathrm{XL}$ guaranteed survival and longevity of the nitrogen fixing bacteria (Bradyrbizobium), and the fungicide Vitavax-Thiram negatively affected these microorganisms. Bueno et al. (2003) tested the survival and nodulation of Bradyrbizobium japonicum with fungicide application and observed results with a significant negative effect of the combinations of Carboxim + Thiram fungicides

\section{CONCLUSIONS}

The xenobiotics did not affect the microbial diversity present in the soils of the tested cultures, being similar statistically with the control.

UFP's crops did not present statistical differences regarding CFU in cultivated soils.

\section{BIBLIOGRAPHIC REFERENCES}

Antunes, LEC, Raseira, MCB. (Org.) (2006). Palestras do II Simpósio Nacional do Morango, I Encontro de Pequenas Frutas e Frutas Nativas do Mercosul. Pelotas: Embrapa Clima Temperado. 145p., 2006. (Documentos 171)

Bueno, CJ, Meyer, MC, \& de Souza, NL. Efeito de fungicidas na sobrevivência de Bradyrhizobium japonicum (Semia 5019 e Semia 5079) e na nodulação da soja. Acta Scientiarum. Agronomy, 25(1), 231-235., 2003.

Duarte, GR. Levantamento e caracterização das plantas alimentícias não convencionais do Parque Florestal de Monsanto-Lisboa (Doctoral dissertation)., 2018.

Embrapa Hortaliças. Hortaliças Não Convencionais Hortalicas Tradicionais: Peixinho. Embrapa Hortaliças: Brasília - DF, 2 p., 2018. 
Embrapa Meio Ambiente. Ecologia da Rizosfera e Filosfera. Disponível em: http://www.cnpma.embrapa.br/unidade/index. php3?id $=228 \&$ func $=$ unid Access in: 11/08/2018. 2018.

Fernandes, M, Procopio, SDO, Teles, DA, de Sena Filho, JG, Cargnelutti Filho, A, \& Andrade, C. Crescimento e fixação biológica de nitrogênio de Gluconacetobacter diazotropicus na presença de inseticidas utilizados na cultura da cana-deaçúcar. Embrapa Tabuleiros Costeiros-Artigo em periódico indexado (ALICE)., 2013.

Figueiró, R. (Org.). Saúde \& Ambiente: da Educação Ambiental à Ecologia de Doenças. $1^{\circ}$ ed, Volta Redonda, RJ. 53 p., 2012.

Gaylarde, CC, Bellinaso, ML, Manfio, GP. Biorremediação: aspectos biológicos e técnicos da biorremediação de xenobióticos. Biotecnologia Ciência \& Desenvolvimento, 34, 36-43, 2005.

Leone, RS. Desenvolvimento de suco de frutas e hortaliças para melhorar a qualidade nutricional e funcional. Viçosa: UFV. 105p (Master Thesis), 2009.

Mapa. Manual de hortaliças não-convencionais. Brasília: Mapa / ACS, 92 p., 2010.

Marks, BB, Bangel, EV, Tedesco, V, da Silva, SLC, Ferreira, SB, Vargas, R, \& Silva, GM. Avaliação da sobrevivência de Bradyrhizobium spp em sementes de soja tratadas com fungicidas, protetor celular e inoculante. Revista Internacional de Ciências, 3(1), 43-51, 2013.

Nakano, O. Vegetable pests: their control and the green-certificate. Horticultura Brasileira, 17(1), 0405, 1999.
Pereira, CE, Oliveira, JA, Caldeira, CM, \& Botelho, FJE. Efeito do tratamento das sementes de soja com fungicidas e período de armazenamento na resposta da planta inoculada com Bradyrhizobium. Revista Agro@ mbiente Online, 4(2), 62-66, 2010.

Procópio, SO, Fernandes, MF, Teles, DA, Sena Filho, JG, Cargnelutti Filho, A, \& Reis, VM. Efeitos de Inseticidas Utilizados na Cultura da Cana-deAçúcar sobre a Fixação Biológica do Nitrogênio in Vitro da Bactéria Diazotrófica Herbaspirillum seropedicae. In: XXIX Reunião Brasileira de Fertilidade do Solo e Nutrição de Plantas, XIII Reunião Brasileira sobre Micorrizas, XI Simpósio Brasileiro de Microbiologia do Solo e VIII Reunião Brasileira de Biologia do Solo. Centro de Convenções do SESC: Guarapari ES, 4 p., 2010.

Reis, MR, Silva, AA, Pereira, JL, Freitas, MAM, Costa, MD, Silva, MCS, ... \& Ferreira, GL. Impacto do glyphosate associado com endossulfan e tebuconazole sobre microrganismos endossimbiontes da soja. Planta daninha, 28(1), 113-121, 2010.

Secretaria de Atenção à Saúde. Departamento de Atenção Básica. Alimentos Regionais Brasileiros. 2 eds., Ministério da Saúde: Brasília - DF, 486 p., 2015.

Silva, EC, Carlos, LDA, Araújo, AP, Ferraz, LDC, Pedrosa, MW, Silva, LS. Characterization of two types of azedinha in the region of Sete Lagoas, Brazil. Horticultura Brasileira, 31(2), 328-331, 2013.

Simon, N, Meneguzzo, A, Calgaro, A. Sistema de Produção de Morango para Mesa na Região da Serra Gaúcha e Encosta Superior do Nordeste. Embrapa Uva e Vinho: Sistemas de Produção, 6, versão eletrônica., 2005. 